\title{
ADVERSE LIFE EVENTS AND COPING SKILLS IN PANIC DISORDER
}

\author{
Mariângela Gentil Savoia and Márcio Bernik
}

SAVOIA MG et al. Adverse life events and coping skills in panic disorder. Rev. Hosp. Clín. Fac. Med. S. Paulo 59(6):337$340,2004$.

Research literature and clinical experience shows that panic patients are often able to identify stressors that preceded the onset of their first attacks. In this study we investigated the relation between life events, coping skills, and panic disorder.

METHODS: Forty-tree panic patients were compared with 29 control subjects regarding the occurrence and the impact of stressful life events in a 1-year period preceding the onset of panic attacks using the Social Readjustment Rating Scale and London Life Event and Difficulty Schedule. Coping skills were measured using the Ways of Coping Questionnaire.

RESULTS: No differences were observed between panic patients and controls regarding the number of reported stressful life events in the previous year. Panic patients compared to controls reported loss of social support as the most meaningful class of events significantly more often. In response to stressful situations, panic patients more often used coping skills judged as ineffective.

CONCLUSIONS: The present study suggests that the type of life event and the coping skills used in response to them, more than the occurrence of stressful events itself, may be associated with the onset of panic disorder.

\section{KEYWORDS: Panic disorder. Life events. Coping skills. Predictors}

Panic disorder patients (PD) are often able to identify and report stressors that preceded the onset of panic. Indeed, panic disorder share many clinical and biological similarities with posttraumatic stress disorder, including that the first panic attack may follow exposure to traumatic stress. ${ }^{1}$ However, in most patients, stressful events preceding the onset of panic disorder are not considered traumatic i.e., events outside the range of normal human experience.

One of the earliest reports on the association of panic disorder and stressful life events by Roth ${ }^{2}$ describes 135 subjects suffering from "phobicanxiety-depersonalization syndrome." Among these, $37 \%$ had experienced the sudden loss or illness of a close relative.
More recently Faravelli \& Palanti ${ }^{3}$ reported a higher recall rate of stressful life events in the 12 months preceding the onset of illness in $64 \mathrm{PD}$ patients $(64.1 \%)$ compared to the control group (34.6\%). Lteif and Mavissakalian ${ }^{4}$ and Horesh et al. ${ }^{5}$ described similar findings. They reported an increased recall of stressful life events in the year preceding the onset of panic compared to latter periods in the same patients.

On the other hand, this association was not corroborated by Pollard et al. ${ }^{6}$,

From the Anxiety Laboratory, Psiquiatry Institute, Hospital das Clínicas, Faculty of Medicine, University of São Paulo - São Paulo/SP, Brazil. E-mail: amban@amban.org.br

Received for publication on January 30, 2004. Accepted for publication on May 31, 2004. who presented strong evidence against a direct correlation between stressful life events and the first episode of panic, and by Schmidt et al.. ${ }^{7}$ who observed that the most important predictor of panic attacks onset during an intense period of stress (military training) was a personal history of panic attacks.

In spite of the diverse findings and conclusions, it is still not understood how such an influence may take place. Given that stressful life events are as undesired as they are inevitable, it is hypothesized that the minority of subjects exposed to them that develop mental symptoms ${ }^{8}$ may have individual predisposing factors, biological and psychological, which interact, leading to the onset of panic attacks. ${ }^{9}$ 
Coping skills is a commonly investigated predisposing factor. Coping is defined as a response to stress (behavioral or cognitive) with the purpose of enduring aversive situations.

Randall $^{10}$ and Becker ${ }^{11}$ proposed that anxiety symptoms may start as negative adaptations to stressful life events as a result of a failure in using effective coping skills. Cox et al. ${ }^{12}$ observed that panic patients, but not controls, used escape and avoidance as usual strategies. Vollrath \& Angst ${ }^{13}$ reported cognitive avoidance and rumination as coping strategies in PD patients during a panic attack. Positive coping behaviors were found to be associated with less mental health service utilization and lower levels of comorbidity in PD patients. ${ }^{14}$

The present study proposes to investigate life events occurring in the year before the onset of panic attacks and the usual coping strategies used to respond to these events.

\section{METHODS}

Forty-three patients (27 females) aged 21 to 58 years (mean $34.8 \pm 7.3$ SD) meeting DSM-IIIR ${ }^{15}$ criteria for panic disorder with or without agoraphobia were included in this study.

Age of onset of panic was 21 to 35 for $65 \%$ of the patients (mean 27.8).At inclusion, $74 \%$ of the patients had 5 or less years of illness.

Initially, 43 controls that matched the patients according to gender, age group, and marital status were selected from hospital personnel volunteering for this study. A structured diagnostic interview ${ }^{16}$ was used to exclude those with a personal history of psychiatric disorders. Data on the 29 controls not excluded (19 females) aged 20 to 49 (mean $33.6 \pm 6.5$ ) were used in this study.

Stressful life events were assessed retrospectively using the Holmes and
Rahe Social Readjustment Scale. ${ }^{17}$ Instead of using the scale as a self-assessment instrument, we used the methodology described by Katsching ${ }^{18}$ in which questions were clarified and answers discussed in a structured interview. A period of 1 year (preceding the interview for controls or the year preceding the onset of the disorder for the panic patients) was used for this evaluation. Six categories of life events were measured using the Social Readjustment Scale ${ }^{17}$ : work, loss of social support, family, environmental changes, personal difficulties, and finances. Subjects and controls were then asked to select up to 3 of them as the most important events in that particular 1year period.

Coping strategies and skills were assessed using Folkman and Lazarus's Ways of Coping Questionnaire. ${ }^{19}$ This scale describes 8 usual coping behaviors: confrontation, withdrawal, self-control, social support, responsibility acceptance, escape and avoidance, problem solving, and positive reappraisal. Subjects reported the strategies used to withstand those 3 most relevant situations. Their answers were tabulated and scores were given to the 8 factors. These scores were weighed according to the number of items found for each factor.

$\mathrm{T}$ tests were used to compare the number of stressful life events reported by each group. Coping skills of patients and controls was compared using the test of comparison of average vectors as described by Morrison. ${ }^{20}$

\section{RESULTS}

Panic patients reported average 3.74 stressful life events in the year preceding the onset of panic. Controls reported an average of 5.66 similar events in the preceding year. This difference was not significant $(P>.90)$. There were also no differences regard- ing the category of the events reported by the patients.

On the other hand there were differences regarding the events chosen as the most meaningful. Subjects in the panic group compared to the control group reported loss of social support as the most meaningful class of events significantly more often. (panic $\mathrm{x}$ controls. $17.05 \%$ x $14.94 \%, \mathrm{f}=2.11$; $P=.01)$.

Regarding the coping skills reported by the patients as most often used in response to stressful situations, panic patients reported the strategy "problem solving" (38.87\% vs $56.46 \%, \mathrm{f}=19.59 ; P<.01)$ and positive reappraisal $(28.02 \%$ vs $47.45 \%$, f $=19.43 ; P<.001)$ less frequently than controls.

\section{DISCUSSION}

Patients attending public hospitals in Brazil usually have cultural deficits. These deficits lead to difficulties in using self-rating scales, such as the Holmes and Rahe Social Readjustment Scale. ${ }^{17}$ Clarifying questions and discussing answers made it possible to deal with such difficulties.

We could not replicate the findings of Faravelli and Pallanti, ${ }^{3}$ Loof et al., ${ }^{21}$ and Pollard et al.6 who all reported higher number of stressful life events in the panic patients. Nevertheless, our findings were confluent with those observed by Rapee et al. ${ }^{22}$ An explanation for this discrepancy may be found in the methodological differences among the studies. In the present study, we opted to instruct subjects to focus on the 3 most meaningful events, which may have influenced subjects in underreporting minor events.

Panic subjects more frequently reported loss of social support as the most meaningful event. This finding is concurrent to the conclusions of Klein ${ }^{23}$ and Faravelli \& Pallanti, ${ }^{3}$ who 


\begin{tabular}{|l|l|l|l|l|l|l|l|l|}
\hline & Factor 1 & Factor 2 & Factor 3 & Factor 4 & Factor 5 & Factor 6 & Factor 7 & Factor 8 \\
\hline Control & 25.52 & 27.28 & 43.95 & 48.66 & 37.37 & 51.33 & 56.46 & 47.45 \\
\hline Panic & 22.28 & 30.55 & 36.40 & 41.74 & 31.03 & 57.27 & 36.87 & 28.02 \\
\hline
\end{tabular}

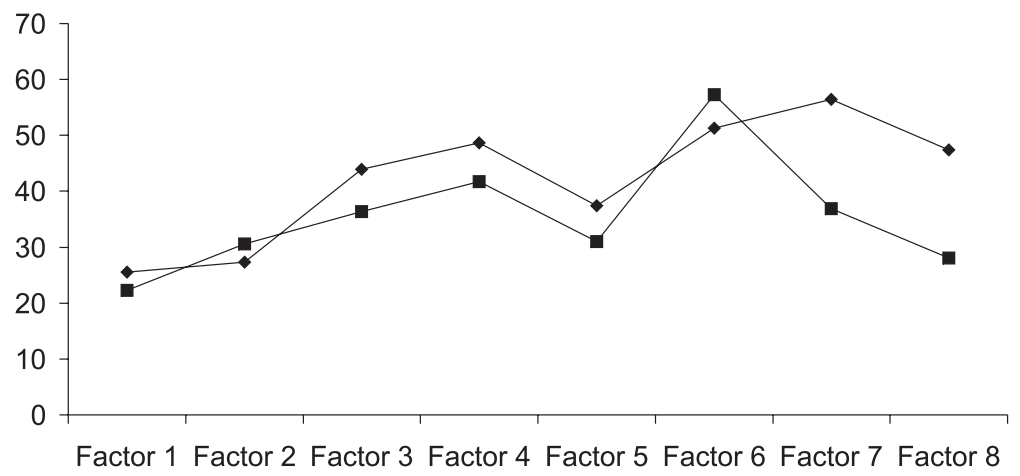

$\rightarrow$ control $\rightarrow$ panic

$\begin{array}{ll}\text { Factor } 1=\text { confrontation } & \text { Factor } 5=\text { responsibility acceptance } \\ \text { Factor } 2=\text { withdrawal } & \text { Factor } 6=\text { escape and avoidance } \\ \text { Factor } 3=\text { self-control } & \text { Factor } 7=\text { problem solving } \\ \text { Factor } 4=\text { social support } & \text { Factor } 8=\text { positive reappraisal }\end{array}$

Figure 1 - Comparison between panic and control groups in factors of coping skills.

verified that the loss of a dear one may be deemed as a precipitating factor for panic disorder.
The present findings are also in agreement with those of Roth et al. ${ }^{24}$ Rapee et al., ${ }^{22}$ Anderson, ${ }^{8}$ and Fleming et al., ${ }^{25}$ according to whom the strategies used to cope with stressful life events preceding the onset of panic are more relevant than the number of events.

Strategies encompassed by factor 8 are positive reappraisal and for factor 7 are problem solving. These strategies describe behaviors that enable people to deal with stressful events in an effective and well-adapted manner. Panic patients used those strategies less frequently than the control group did. This finding suggests that the strategies used by panic patients may be less effective and inappropriate for dealing with stressful situations. Cox et al. ${ }^{12}$ and Vollrath and Agnst ${ }^{13}$ reported similar conclusions.

In conclusion, despite the methodological limitations associated with a retrospective study design and that raters were not blind to the subject group, the present study suggests that the impact of life events in subjects predisposed to panic disorder is associated with the strategies used to cope with them.

\section{RESUMO}

SAVOIA MG e col. Relação entre eventos vitais adversos e estratégias de enfrentamento com o transtorno de pânico. Rev. Hosp. Clín. Fac. Méd. S. Paulo 59(6):337-340, 2004.

Os relatos da literatura e a experiência clínica tem demonstrado que pacientes com transtorno de pânico são capazes de identificar estressores que precederam o primeiro ataque de pânico. O objetivo deste trabalho é investigar a relação entre eventos vitais, estratégias de enfrentamento a estresse e transtorno de pânico.

MÉTODO: Foram comparados 43 pacientes com transtorno de pânico com 29 sujeitos controle no que diz respeito a ocorrência e impacto dos eventos vitais estressores no ano que precedeu o primeiro ataque de pânico. Para tanto utilizou-se a Escala de Reajustamento Social e London Life Event and Difficulty Schedule. As estratégias de enfrentamento foram avaliadas pelo Inventário de Estratégias de Coping.

RESULTADOS: O número de eventos vitais estressores relatados por ambos os grupos era estatísticamente equivalente. Os sujeitos do grupo experimental mas não os do grupo controle relataram perda de suporte social como a mais importante classe de eventos vitais. As estratégias de enfrentamento utilizadas em resposta aos eventos estressores foram pouco efetivas e desadaptadas, diferentemente do grupo controle.

CONCLUSÕES: O presente estudo indica que não é o número de eventos vitais que determina a relevância de sua ocorrência para os pacientes de pânico, mas as estratégias de enfrentamento utilizadas, bem como o significado adverso atribuído aos eventos e o impacto desses eventos em suas vidas.

UNITERMOS: Transtorno de pânico. Eventos vitais. Estratégias de enfrentamento. Preditores. 


\section{REFERENCES}

1. Falsetti AS, Resnick HS, Dansky BS, Lydiard BR, Kilpatrick DG. The relationship of stress to panic disorder: cause or effect? In: Mazure, CM, editors. Does stress cause psychiatric illness? American Psychiatric Press, Washington DC, 1995. p. 25-32.

2. Roth M. The phobic anxiety-depersonalization syndrome. Proceedings of the Royal Society of Medicine 1959;52:58796.

3. Faravelli C, Pallanti S. Recent life events and panic disorder. American Journal of Psychiatry 1989;146:622-6.

4. Horesh N, Amir M, Kedem P, Goldberger Y, Kotler M. Life events in childhood, adolescence and adulthood and the relationship to panic disorder. Acta Psychiatry Scandinavian 1997;96:3738 .

5. Lteif GN, Mavissakalian MR. Life events and panic disorder/ agoraphobia: a comparison at two time periods Compr Psychiatry 1996;37:241-4.

6. Pollard A, Pollard HJ, Corn KJ. Panic onset and major events in the lives of agoraphobics: a test of contiguity. Journal of Abnormal Psychology 1989;98:318-21.

7. Schmidt B, Lerew DR, Jackson RJ. The role of anxiety sensitivity in the pathogenesis of panic: prospective evaluation of spontaneous panic attacks during acute stress. Journal of Abnormal Psychology 1997;106(3):355-64.

8. Anderson MP. Stress management for chronic disease: an overview. In: Russell M L. Stress Management for Chronic Disease. Oxford: Pergamon Press;1988. p. 3-13

9. Graeff F. Neuroanatomy and neurotransmitter regulation of defensive behaviors and related emotions in mammals. Brazilian Journal Med Biological Research 1994;27:811-29.

10. Randall D. Concepts of health and mental health: laying the groundwork for intervention. Canada Mental Health 1981;1 (Suppl):1-6.

11. Becker A. Life events as predisposing factors for mental disorders: source psychological considerations. In: Katschining H. Life events and Psychiatric disorders: controversial issues. Cambridge: Cambridge University Press;1986. p. 63-73.

12. Cox BJ, Endl N, Swhinson RP, Norton GR. Situations and specific coping strategies associated with clinical and non-clinical panic attacks. Behavior Research and Therapy 1992;30;67-9.
13. Vollrath M, Angst J. Coping and illness behavior among young adults with panic. The Journal of Nervous and Mental Disease $1993 ; 181: 303-8$

14. Katerndahl DA, Talamantes M. A comparison of persons with early- versus late-onset panic attacks. Journal of Clinical Psychiatry 2000;61:422-7.

15. American Psychiatry Association. Diagnostic Statistic Manual of Mental Disorders - Third Edition Revised, Washington: 1987.

16. Wiens AN, Matarazzo JD. Diagnostic interviewing. In: Kasdin A, Bellack A. Clinical Pscychology Handbook. New York Pergamon Press;1991. p. 309-338.

17. Holmes TH, Rahe RK. The social readjustment rating scale. Journal of Psychosomatic Research 1967;4:189-94.

18. Katschinig H. Prospects for future research In: Katschinig H. Life events in psychiatric disorders: controversial issues. Cambridge: Cambridge University Press;1986. p. 246-256.

19. Folkman S, Lazarus LR. If it changes it must be a process: study of emotion and coping during three stages of a college examination. Journal of Personality and social Psychology 1985;50:992-1003.

20. Morrison DF. Multivariate statistical methods. McGraw Hill, New York: 1976

21. Loof C, Zandbergen H, Lousberg H, Bols H, Griez, E. The role of life events in the set of panic disorder. Behaviour Research and Therapy 1988;27:461-3.

22. Rapee RM, Litwin EM, Barlow DH. Impact of life events on subjects with panic disorder and on comparison subjects. American Journal of Psychiatry 1990;147: 640-4.

23. Klein D. Anxiety: new research and change in concepts. New York: New York Raven Press;1980.

24. Roth WT, Margraf J, Ehlers A, Taylor B, Maddock RJ, Davies S, et al. Stress test reactivity in panic disorder. Archives Gener of Psychiatry 1992;49:301-10.

25. Fleming R, Baum A, Singer JE. Toward an integrative approach to the study of stress. Journal of Personality and Social Psychology 1984;46:939-49. 